\title{
A Study of Student Perceptions Related to Friendship Value in Turkish Language and Literature Course Program with Metaphors
}

\author{
Fatma Süreyya Kurtoğlu
}

Faculty of Education, Gazi University, Turkey

Copyright $\mathrm{O} 2019$ by authors, all rights reserved. Authors agree that this article remains permanently open access under the terms of the Creative Commons Attribution License 4.0 International License

\begin{abstract}
Today, despite all sorts of scientific and technological advancements, financial and moral dissatisfaction, unhappiness, and dissatisfaction from life, mercilessness, intolerance, injustice, disloyalty and indifference to what is taking place have been increasing in Turkey, together with the whole world. Countries realizing this issue have made a number of efforts in order to give national and universal values to new generations, which also can be considered as principles of living together, to make them alive and effective again and create some new values convenient for the era. Social control that has almost vanished is aimed to be regained with these efforts. In this study, the perceptions of "friendship" value of $9^{\text {th }}$ graders in secondary education institutions in central Ankara, which is also included in Turkish Language and Literature Course Teaching Program, were tried to be determined with metaphors. In the research, which was conducted in scanning model with qualitative research pattern, data gathering with metaphors that is a qualitative research technique, which is seen appropriate for data gathering, was used. The study group of the research consists of 107 male and 60 female students (with a total number of 167) who were taking education in five secondary education institutions in central Ankara districts in 2017-2018 academic year's Spring term. As a result of the research, the participants developed 20 different metaphors and these metaphors were grouped into five categories as "Gain Meaning With", "Result Depending on Importance Shown", "Giving Happiness with its Existence", "Indispensable", and "Guide". Most of the 20 different metaphors on friendship value developed by the participants were described as positive with abstract words; however, few descriptions that had negative connotations were also found. The participants had positive ideas about friendship mostly related to words with concrete meanings, and it can be evaluated that a value like friendship with abstract and moral aspect is materialized.
\end{abstract}

Keywords Turkish Language and Literature Course,
Friendship, Perception, Metaphor

\section{Introduction}

The concept of value which is described as "the collection of materialistic and spiritual elements covering social, cultural, economic and scientific values of a nation" [62] is everything that is sociologically beneficial for the individual and the group, desirable for the individual and the group and liked by the individual or the group [5]. Values are also "the collection of all sorts of senses, thinking, attitudes, rules or dignity that have social, humanistic, ideological or religious origins that have been accepted, adopted and sustained in a society, a belief, an ideology or among people" [15], and "the conscientious criteria with which an individual manages to organise his own behaviour in favour of the society and individuals he lives with, and to control his ideas and behaviour in order to reach what is good and right" [29]. This concept was first brought into social sciences by Znaniecki [8].

The individual gets historical customs and traditions from the society he belongs to or, with some universal approaches, a set of norms such as good, bad, nice, ugly, favour, help, compassion, and courage. The order he gets according to the nation he belongs to determines that society's national values and the one he gets according to universal point of view determines the universal values [66]. Values are a system that make nations different from each other and they include national characteristics. These are also sensitivities that individuals face in any sort of event or situation [36]. Values are adopted by the individual, approved by the society and they are also consistent with other values that belong to the society [22]. We can roughly divide them as social and individual values. Social values provide individuals with common behaviour. Therefore, conflicts within the society are reduced and 
preservation of society is provided. Individual values, on the other hand, play an important part in individual's personality and the development of his character [22].

A considerable amount of classifications in studies on values has been tried up to this day. One of the highly accepted classifications was made by Spranger (1928). In Spranger's classification, values were divided into six groups as scientific, economic, aesthetic, social, political and religious. This grouping was later converted into a scale by Allport, Vernon and Lindzey (1951) [1]. Into these six values, Güngör had added moral value including honesty, righteousness, tolerance and helpfulness [22]. Philosophers, on the other hand, had followed a different way by taking subjective and objective standpoints into consideration in value classifications. Classification made according to this approach consists of the following headings: "Hedonist values (positive: joy; negative: pain), cognitive values or knowledge values (positive: right; negative: wrong), moral values (positive: good; negative: bad), aesthetic values (positive: nice; negative: ugly), religious values (positive: deed; negative: $\sin$ )" [48].

Societies are in need of passing the values they have down to next representatives. "Since values owned are the elements to shape individual's personality, standpoint, behaviour and even his life in the future, it is essential for the individual to realise certain values, gain necessary values, adopt new values and transform these values into behaviour by making them the foundations of his personality. This long-lasting gaining process is called values education" [70].

Studies conducted in Europe and the USA on how to manage values education have been in common all over the world, and they have also gained importance in our country in terms of determining these values, making them common and in this way, providing social control, resulting in numerous researches $[1,6,7,9,17,21,22,37,42,43,46$, $50,57,68,67,70,71$ etc.].

Ministry of National Education has also inserted values targeted to be gained by the individuals into elementary and secondary educations' curriculums and it was aimed to convey these values to new generations with the help of these courses and units [36]. In this context, it is emphasized in Turkish Language and Literature Course Teaching Program aiming at letting students to comprehend the national, spiritual, moral, cultural and universal values [60] that, with the help of works of Turkish literature, education system is not particularly a structure that puts academic success in the first place by giving some pre-determined knowledge, skills and behaviour and that the main aim of education system is to raise individuals who adopted the foundations of values and to be able to affect their habits and behaviour [60].

"It is an undisputable fact that a nation's future is dependent on the people who have adopted their values and embodied them with abilities they own. That is why our education system acts in order to make convenient moral decisions on every single member of it and to gain the sufficiency and ability to perform these in their behaviour. (...) Education program is formed by taking into consideration of all elements of education system such as teaching programs, learning and teaching environments, materials and tools of teaching, extra-curricular activities, and curriculum. In this point of view, in our teaching programs, our values have not been seen as a separate program or learning field, unit or subject. On the contrary, the ultimate aim of all the education programs and our values that have a soul has been in every single teaching program and unit." [60].

Ministry of National Education has adopted values education subject with a set of activities at schools and has included some targets in course teaching programs that had been formed with the idea "to insert some universal and national values into new generations and to provide students who finished high school education by becoming individuals that are ready for a profession in relation with their interests and skills, and for higher education and life by improving their skills gained at elementary and secondary schools and the Ministry also set these targets to enable these students to become individuals who have adopted national and moral values and made them their lifestyles by contributing into our country's economic, social and cultural development as productive and active citizens and who have gained basic level skills and proficiencies that take part in "Turkey Proficiency Frame" and also in fields related to disciplines" [60].

With a circular letter, it was reminded that many political, economic, social and cultural occasions in globalising world had been threatening social life; it was also stated that several national and universal values were needed in order to protect individuals and society from negativities and it was aimed to improve the skills of students in all state and private education institutions of the Ministry and to reflect them in behaviour. The attachment of the circular letter also included a list of "Activity Examples Related to Value Education" [19].

Basic values such as justice, friendship, honesty, self-control, patience, respect, love, responsibility, patriotism and helpfulness in teaching programs were determined and it was emphasized that these values were to be embodied by going over together with related sub values and also with other basic values in learning/teaching process [60].

It is possible to talk about different approaches in activating values education in schools. These approaches have unique philosophical and political basics and also an educational application plan of their own. In these educational applications, it can be claimed that the values education activities aimed to be given to the students are sometimes realised with recommendation approach, moral reasoning, value explanation approach, value analysis approach and with observation by using learning approach as the base $[1,32,69]$. 
Generally, it is observed that the individual is in the first place and that the effects of dynamics of society are gradually weakening. Humanity's unhappiness, not being contended with what one owns, dissatisfaction, intolerance to what is different, etc. are becoming all societies' common problem. Today, where it is easier to be in touch with different cultural structures, individual's acquaintance with his own society's values is getting weaker and people's academic and financial achievements come first. Consequently, an individual that more or less achieves academic and financial success cannot even realise that he is becoming isolated from public sharing, thus, slowly turning into a selfish and pragmatist person in his relationships. In this context, it is doubtless to say that some national and universal values such as "justice, friendship, honesty, self-control, patience, respect, love, responsibility, patriotism, helpfulness, etc.", which are aimed to be gained in Course Teaching Programs by the end of secondary education, are quite important in order to establish a wealthy society.

One of the values that is aimed to be given to the students in Turkish Language and Literature Teaching Program is "friendship". This concept, which is thought to be vanishing and differentiating, is one of the most needed elements of a healthy public life.

Many artists from literature world have directly or indirectly stated their opinions on this concept while mentioning their friends. In his work Edebü'd-dünyâ ve'd-dîn, İmam Mâverdî, who is the author of one of the most systematic moral books that covers friendship subject in traditional Islamic view, showed friendship and love as acquaintanceship, which is one of the necessities of preserving the order in individual and social life [14].

In his famous work Essays, French writer and philosopher Montaigne wrote: "What we call friendship is a coincidence that makes our souls be together or affections we gain by necessities. In friendship, souls are so close, attached and joined together that the stitches might eventually become invisible. If they want me to tell why I love him (Etienne De La Betie) I believe I can put it only this way: Because he was just himself; and I was just me." [44]. Ahmet Hamdi Tanpinar, one of the most important figures of Turkish literature describes his intimate friendship with Nurullah Ataç as: "Friendship is a fate, too. And it is a good fate. In the beginning of every considerable action and each idea movement, there flows a fountain. In the beginning of every great work, there waits the face of a friend disguised as an angel. The path of cause is always tough. It is essential for the shoulders to touch each other and for the songs to mix with each other in order not to stop in the middle. Fame, the feeling of what you are doing, pride as a crown of foolishness, wrath or hate cannot go beyond a small and blinding drunkenness next to his warmth. (...) Only the palace of friendship has no cracks and its roof does not leak." [58]. Mustafa Kutlu, an acclaimed story writer and columnist in
Turkish literature writes: "Friend is (...) the person you can put your head on his shoulder and cry. He does not stab you in the back. Friendship is based on love, respect, sacrifice and relinquish. It requires service, respect, mercy and affection. Friend is the one who gets you back on your feet." [38].

Metaphor, originally a Greek word that has been used in all Western languages, finds its meaning in Turkish with concepts such as projection [47], idiom transfer [2], figure of speech [24, 27], borrowing [13] and metaphor [56].

Metaphor, which has the meaning of "Using a word or a concept to have other meanings apart from the accepted ones" [64] in Turkish Dictionary, is described by Hançerlioğlu as "borrowing something's name in order to describe something else which is compared to" [24] and according to İnce, metaphor is "Referring something as something else's name with which it is alike in certain ways. In this sense, borrowing is the art of both figure of speech and likening." [27]. Metaphor (figure of speech) as a literature term, is the use of a word other than its real (basic) meaning. In metaphor, the relationship between the word and the meaning it shows is out of reality. There has to be a relationship between these two meanings in order to show the metaphorical meaning, not the first (real/basic) meaning." [56].

"The term "metaphor" is a product of mind occurring as a natural output from a person's potential language skills since it is basically an act of "language" although it has been given different meanings and functions in the West and the East." [18]. Metaphors have the function to reflect individuals' past experiences, present ideas, and hopes for the future, as well as their points of views [40].

Metaphor usage generally means a form of thought or approach that comes in our perception of the world. In this context, metaphor is a mental tool an individual can make use of while understanding a highly abstract, sophisticated or theoretical concept [54, 42].

Language that is loaded with metaphors is seen in literary texts most of the time and it is being used in all fields related to mass communication today and it has almost become a characteristic of daily language. "Metaphors as a mental model for giving meaning to abstract or theoretical concepts and describing them may increase the quality of learning process by establishing effective connections and creating images between the individual's past learnings and experiences and concepts freshly learned." [41].

Metaphors are increasingly used in education and in many other fields as well. According to Keray Dinçel and Yilmaz, metaphors make it easier to teach concepts by likening in hard topics and they also work well when getting deeper into individuals' thoughts [31]. Metaphors, according to Carter (1990), are quite useful while describing mental activity teaching requires. They provide communication with tools in real meaning, which is also 
not impossible but difficult [as cited in 31].

Metaphor use in education and teaching activities provide significant contributions into the improvement of thinking skills and creativities of learners, embodiment of abstract concepts that are difficult to comprehend, active participation of learners into education, facilitating the understanding of scientific concepts and keeping them in mind for a longer period of time and also the improvement of scientific thinking and problem solving skills [26].

There have been many studies about metaphor made in different fields of social sciences. Some of these include: how employees perceive the institutions they work at [54, 28 etc.], how to use metaphors as tools that make it easier for children to learn [42 etc.], how teachers perceive the students and how the students perceive teachers $[12,65$ etc.], how they function identically in explaining organizational change [16], the analysis of perceptions related to some values in course teaching programs $[33,34$, 67 etc.], students' perceptions on some courses and their teachers $[49,59]$, the analysis of some concepts related to language and literature $[3,22,32,52$ etc.]

The aim of this research is to determine how friendship value, which is included in $9^{\text {th }}$ grade Turkish Language and Literature Course Teaching Program, is perceived by the students and to determine metaphors and metaphor categories created accordingly.

Therefore, the following questions have been asked:

What are the metaphors the participants developed related to friendship value?

In which categories are these metaphors put?

\section{Method}

In order to determine how secondary education $9^{\text {th }}$ grade students perceive friendship value that is included in Turkish Language and Literature Course Teaching Program, qualitative research techniques of data gathering by metaphors and their analysis were used in the research.

\subsection{Research Pattern}

The research, which aims to put forth the teacher candidates' perceptions on friendship value - one of the basic values in Turkish language and literature teaching program, was designed and conducted according to qualitative research paradigm. Qualitative research is defined as a way where qualitative data gathering methods such as observation, interview and document analysis are used and where a qualitative process is followed allowing perceptions and actions to happen in natural environment and in a realistic and complete way $[72,30]$.

\subsection{Study Group}

In the study, "forming sampling based on maximum diversity", which is one of the aimed sampling methods, was used. In forming sampling based on maximum diversity, the aim is to find whether there are common or shared concepts between varying situations for making generalizations and to put forward the different dimensions of the problem according to this diversity [72]. It can be claimed that there are two advantages of forming sampling based on maximum diversity method as deeply describing every situation related to sampling in their own dimensions and determining shared categories that may occur between situations that show different characteristics [51].

In this context, the study group of the research consists of 107 male and 60 female students (with a total number of 167) who were taking education in five secondary education institutions in central Ankara districts in 2017-2018 academic year's Spring term.

\subsection{Data Gathering Tools}

In order to determine the metaphors related to meanings that the secondary education $9^{\text {th }}$ grade students have given to friendship value in Turkish Language and Literature Course Teaching Program, data gathering form with metaphors previously used by some other researchers [4, $23,33,34,35,46,50,53,54,55]$ was used. The participating students were asked to fill in the form that included two prompts such as: "Friendship is like ...............; Because ...............

Metaphor (figure of speech) is generally described as a thinking form and an approach in our perception of the world [45]; thinking on something about something else and an element of humanistic thinking in order to better understand concepts [39], a word used in its other meanings than its real meaning as a result of an interest or likening, using a word or a concept in other meanings than the accepted ones $[61,63]$ and it is also seen as a mental image an individual might make use of while explaining a highly abstract and sophisticated concept $[53,73]$. In other words, metaphor is the expression of differences in interpretations consisted of personal experiences [42].

\subsection{Data Gathering}

Data gathering process was conducted in an application step. In this step of the research (May 2018), every student was given a metaphor form related to friendship value in Turkish Language and Literature Course Teaching Program. Before the research, the researcher gave brief information about herself and the aim of the research. Before moving into how the research was going to be made, the instructions on the form given to the students were read out and the students were informed about the research.

\subsection{Data Analysis and Interpretation}

Content analysis was used in collected data analysis. The aim in content analysis is to reach concepts and relations that can explain the data gathered. This technique is always 
convenient for the analysis of texts that are high in number. In this context, the aim of content analysis is to determine and evaluate common information, which is important in terms of research question in texts that are high in number [20] and to reach concepts and relations that can explain the data gathered [10]. Büyüköztürk (et.al). describes content analysis as a technique that provides opportunity for indirect studies about individual behaviour.

Data analysis and interpretation was conducted in five steps:

- In Coding and Elimination Step, data gathered from participants were given numbers and they were coded and 139 non-contributing forms were eliminated and left out of evaluation. These forms included blank sheets or the ones with insufficient expressions despite there were metaphors given or the ones only with the description of the research topic's value. Some of these sheets included: "Friendship is like brotherhood. Because friendship is same as brotherhood. It is the one who stands by you for better and for worse." (K161), "Friendship is like confidant. Because you can share what you cannot tell most people with your friend." (K158), "Friendship is like the sky and birds staying together. Because it is like birds loving the sky, fish loving the sea, trees loving water and people loving each other and establishing brotherhood." (K164), "Friendship is like a bird. Because if you squeeze it in your hands, it will eventually die. If you hold it loose, it will fly away." (K119), "Friendship is like universal. Because everyone has a friend. And these friends do not have to be people. Any object or a living thing can be a friend." (K160). Gathered metaphors were alphabetically put in order in excel program.

- In Compiling Sample Metaphor Step, "metaphor analysis" used by Saban [55] and "content analysis" mentioned by Yıldırım and Şimşek [72] methods were used and each metaphor produced was separated from each other. This way, metaphors produced by the participants were revised and the connection between the correspondent and the corresponding was evaluated. As a result of this evaluation, forms with poorly structured images were eliminated and 28 metaphors about friendship value were collected from 167 participants with 20 different ones.

- In Forming Categories Step, metaphors developed by participants about friendship value were divided into categories by taking their reasons into consideration. NVivo 10 program was used in forming categories.

- In Validity and Reliability Step, in order to find out whether the metaphors in metaphor categories collected in this part represented conceptual categories they belong to, metaphor lists and the lists including conceptual categories that were formed differently were examined by the researcher and a field expert by taking Miles and Huberman's [74] formula (consensus/ consensus + dissensus) into consideration. As a result of the examination, the matches of the researcher and the field expert were compared to each other and $92 \%$ reliability was found out. It was concluded that the current study was reliable since this reliability value confirms the point of view by Saban [55] that having $90 \%$ or more correlation between evaluations by different evaluators in qualitative researches shows a desired level of reliability.

- Transferring Collected Data into Computer Platform: In this step, metaphors categorized and the number of participants representing the categories they are in (f) were calculated. Codes belonged to participants (K1, $\mathrm{K} 27$, K63, etc.) were used in reporting the exact quotations related to metaphor reasons.

\section{Findings}

Answers to the research questions are combined and presented in Table 1 together with expression frequencies.

Table 1. Metaphors Developed by Participants on Friendship Value

\begin{tabular}{cccccc}
\hline No & Metaphor & $\mathrm{f}$ & No & Metaphor & $\mathrm{f}$ \\
\hline 1 & Adana Kebab & 1 & 11 & Breathing & 2 \\
\hline 2 & $\begin{array}{c}\text { Hour \& Minute } \\
\text { Hand }\end{array}$ & 2 & 12 & Daisy & 1 \\
\hline 3 & Mirror & 1 & 13 & Daisy Leaves & 1 \\
\hline 4 & Half of an Apple & 2 & 14 & Money & 1 \\
\hline 5 & Sycamore & 1 & 15 & $\begin{array}{c}\text { Flower and Earth } \\
\text { in a Pot }\end{array}$ & 1 \\
\hline 6 & Flower & 4 & 16 & Pack of Cigarettes & 1 \\
\hline 7 & Marriage & 1 & 17 & Rhyme in a Poem & 1 \\
\hline 8 & Shadow & 2 & 18 & Pan and Egg & 1 \\
\hline 9 & Book & 1 & 19 & Star & 2 \\
\hline 10 & Cat in Need & 1 & 20 & Home & 1 \\
\hline & Total & & & & 28 \\
\hline
\end{tabular}

When Table 1 is studied, it is seen that participants developed 20 different metaphors on friendship value. More than half of the metaphors developed (14) is represented by only one participant. The remaining 6 metaphors are represented by 2-4 participants. Average participant per metaphor is approximately 1,4 . When frequency distribution of metaphors on friendship value is studied, it is seen that the most frequently used ones are "flower", "half of an apple", "shadow", "breathing" and "star",

Categories Formed As a Result of the Answers to the research questions are combined and presented in Table 2. 
A Study of Student Perceptions Related to Friendship Value

in Turkish Language and Literature Course Program with Metaphors

Table 2. Metaphor Categories the Participants Have on Friendship Value

\begin{tabular}{ccccc}
\hline No & Category Name & Metaphor & $\begin{array}{c}\text { Metaphor } \\
\text { Number }\end{array}$ & Total Metaphor \\
\hline 1 & Gain Meaning With & $\begin{array}{c}\text { Hour \& Minute Hand, Half of an Apple, Shadow, } \\
\text { Daisy Leaves, Flower and Earth in a Pot, Pan and Egg }\end{array}$ & 6 & 9 \\
\hline 2 & $\begin{array}{c}\text { Result Depending on } \\
\text { Importance Shown }\end{array}$ & $\begin{array}{c}\text { Sycamore, Flower, Cat in Need, Daisy, Pack of } \\
\text { Cigarettes }\end{array}$ & 5 & 8 \\
\hline 3 & $\begin{array}{c}\text { Giving Happiness with Its } \\
\text { Existence }\end{array}$ & Adana Kebab, Money, Star, Home & 4 & 5 \\
\hline 4 & Indispensable & Marriage, Breathing, Rhyme in a Poem & 3 & 4 \\
\hline 5 & Guide & Mirror, Book & 2 & 2 \\
\hline
\end{tabular}

According to Table 2, metaphors the participants developed on friendship value are grouped under 5 conceptual categories in terms of common points. Each metaphor is grouped under the opinion context that forms the source (reason) of the metaphor as a result of participants' expressions. Accordingly:

\section{Category 1: Gain Meaning With}

When Table 2 is studied, it is seen that "Gain Meaning With" category includes a total of 6 metaphors and 9 participants. When the frequency distributions of metaphors in this category are examined, the most frequently used ones are "Hour \& Minute Hand", "Half of an Apple" and "shadow". Below are the examples of reasons why the participants developed metaphors forming "Gain Meaning With" category:

"Friendship is like hour and minute hand, like a bridge. Because they don't have a meaning without each other. They complete each other." (K23).

"Friendship is like a half of an apple. Because they don't have a meaning once they are separated. But they are complete when put together. Friendship is the same, two of them complete each other..." (K57).

\section{Category 2: Result Depending on Importance Shown}

When Table 2 is studied, it is seen that "Result Depending on Importance Shown" category includes a total of 5 metaphors and 8 participants. When the frequency distributions of metaphors in this category are examined, the most frequently used one is "flower". Below are the examples of reasons why the participants developed metaphors forming "Result Depending on Importance Shown" category:

"Friendship is like a flower. Because it blossoms with love. But it fades away if there is no love or water. The more love you show to your friend, the longer the friendship becomes." (K20).

"Friendship is like a daisy. Because you take care of it so that it doesn't fade. You water it every day. But if you water it too much, it fades. Just like friendship..." (K77).

\section{Category 3: Giving Happiness with Its Existence}

When Table 2 is studied, it is seen that "Giving
Happiness with Its Existence" category includes a total of 4 metaphors and 5 participants. When the frequency distributions of metaphors in this category are examined, the most frequently used one is "star". Below are the examples of reasons why the participants developed metaphors forming "Giving Happiness with Its Existence" category:

"Friendship is like a star, because a friend is always with you in your good and bad days. He's not always there like a star but you know he exists." (K125).

"Friendship is like money, because you are happy if you have money. You become unhappy if you run out of money. A friend is the same. You are happy if you have a friend and you are not happy if you don't have a friend." (K115).

\section{Category 4: Indispensable}

When Table 2 is studied, it is seen that "Indispensable" category includes a total of 3 metaphors and 4 participants. When the frequency distributions of metaphors in this category are examined, the most frequently used ones are "ocean" and "antique". Furthermore, below are some examples of reasons why the participants developed metaphors forming "mysterious and valuable" category:

"Friendship is like breathing. Because a person cannot live without breathing and he cannot live or stay strong without friends..." (K29).

"Friendship is like a rhyme in a poem, because rhymes go in harmony. A poem without rhymes make no sense. Just like friendship friends are in harmony with each other. If there is no harmony, nothing will happen..." (K82).

\section{Category 5: Guide}

When Table 2 is studied, it is seen that "Guide" category includes a total of 2 metaphors and 2 participants. When the frequency distributions of metaphors in this category are examined, it is seen that each metaphor is represented by one participant. Below are some examples of reasons why the participants developed metaphors forming "guide" category:

"Friendship is like a book. Because in friendship, we tell our friend everything. And he collects them like a book. Then he tells us what is right and wrong. He guides us to good things..." (K55). 
"Friendship is like a mirror. Because when you look at the mirror, you see yourself. (...) When we look at our friend, we see someone like ourselves." (K147).

\section{Result and Recommendations}

In this study, the perceptions of "friendship" value of $9^{\text {th }}$ graders in secondary education institutions in central Ankara, which includes the Turkish Language and Literature Course Teaching Program, were tried to be determined with metaphors.

As a result of the research, the participants developed 20 different metaphors and these metaphors were grouped into five categories as "Gain Meaning With", "Result Depending on Importance Shown", "Giving Happiness with its Existence", "Indispensable", and "Guide".

It was concluded that the category with the most metaphors was "Gain Meaning With" (6 metaphors), and the category with the least metaphors is "Guide" (2 metaphors).

The most produced metaphors about friendship value are "flower" (4 participants), "half of an apple" ( 2 participants), "shadow" (2 participants), "breathing" ( 2 participants) and "star" (2 participants).

Most of the total 20 different metaphors developed by the participants on friendship value are concrete words that have positive connotations such as "Adana kebab, pan and egg, book, money, apple, star, daisy, breath" whereas there are few expressions with negative connotations such as "pack of cigarettes, cat in need". That friendship is likened to an object like meal or money shows that positive views on friendship dominate the age group studied; however, it can also be evaluated that these values are being isolated and have become numb, and an abstract and moral value like friendship is objectified since these values are mainly expressed with concrete words in a pure benefit environment. Unfortunately, this result that can be generalized corresponds to the views and report entitled "Danger of An Insensitive Generation" by an inspector who was assigned to investigate the murder of a school principal by two students in Ödemiş, İzmir: "A generation that is indifferent to the realities of life, insensitive and selfish is coming. They do not understand their own parents who cry for those who died at wars. It does not make any sense for them to cry for other people's children. They do not care about the wars at our doorsteps, children in pain, or tens of thousands of people dying. They watch all the painful realities like in a cartoon and their hearts do not ache. Main focus of their lives is to have fun. They see the times they cannot have fun as torture for them. They are not aware of the sacrifices done for them. They do not cherish, and they are disloyal. They see everyone as servants for them. The value they give to people is correlated with to what extent their desires are met and how much fun they can have." [25]
This situation can also be considered as one of the negative aspects of the current system used in student placements in secondary education institutions. Because it is harder for these students, who are simply picked from different socioeconomic regions of the city according to the scores they get in exams, to have real friendships since they do not have time to share anything with each other out of school environment. This negative situation can be turned into a positive one by serious and particular efforts on individuals at learning ages with the help of teachers, schools, families, media cooperation and by enabling the students to gain values such as tolerance, generosity, sacrifice and patience that are or will be in course teaching programs.

\section{REFERENCES}

[1] Akbaş, O. (2004). Türk Millî Eğitim Sisteminin Duyuşsal Amaçlarının (Değerlerinin) İlköğretim II. Kademedeki Gerçekleşme Derecesinin Değerlendirilmesi. Doktora Tezi, Ankara: Gazi Üniversitesi.

[2] Aksan, D. (2006). Anlambilim. Ankara: Engin Yay.

[3] Aslan, H. ve Doğan, Ü. (2016). "Üstün Yetenekli Öğrencilerin Devam Ettikleri Okulları İle Bilim ve Sanat Merkezine İlişkin Metaforik Algıları: Karşılaştırmalı Durum Çalışması". Abant İzzet Baysal Üniversitesi Eğitim Fakültesi Dergisi. 16 (2): 335-350.

[4] Aydın, F. (2010). "Ortaöğretim Öğrencilerinin Coğrafya Kavramına İlişkin Sahip Oldukları Metaforlar”. Kuram ve Uygulamada Eğitim Bilimleri Dergisi. 10(3): 1313-1322.

[5] Aydın, M. (2011). "Değerler, İşlevleri ve Ahlak". Eğitime Bakış. 19, 39-45.

[6] Biçer, S. (2013). Değerler Eğitimi Açısından Mehmet Akif Ersoy'a Ait Safahat Adlı Eserin İncelenmesi. Yüksek Lisans Tezi. Uşak: Uşak Üniversitesi.

[7] Bildirici, H. (2006). Selim İleri'nin Hikâyelerinde Dostluk Temasının Açılımları. Yüksek Lisans Tezi. Kırıkkale: Kırıkkale Üniversitesi.

[8] Bilgin, N. (1995). Sosyal Psikolojide Yöntem ve Pratik Çalışmalar. İstanbul. Sistem Yay.

[9] Bulut, S. (2011). Atasözlerinin Değerler Eğitimindeki Yeri. Yüksek Lisans Tezi, Trabzon: Karadeniz Teknik Üniversitesi.

[10] Büyüköztürk, Ş., Kılıç-Çakmak, E., Akgün, Ö. E., Karadeniz, Ş. ve Demirel, F. (2010). Bilimsel Araştırma Yöntemleri. (7. Bask1). Ankara: Pegem A Yay.

[11] Bybee, R. W. ve Sund R. B. (1990). Piaget for Educators. Illinois: Waveland Press.

[12] Cerit Y. (2008). “Öğretmen Kavramı İle İlgili Metaforlara İlişkin Öğrenci, Öğretmen ve Yöneticilerin Görüşleri”. Türk Eğitim Bilimleri Dergisi. 6(4): 693-712.

[13] Coşkun, M. (2010). Sözün Büyüsü-Edebî Sanatlar. İstanbul: 
Dergâh Yay.

[14] Çağrıcı, M. (1994). "Dostluk”. Türkiye Diyanet Vakfı İslam Ansiklopedisi. 9: 511-513.

[15] Çelikkaya, H. (1996). Fonksiyonel Eğitim Sosyolojisi. İstanbul: Alfa Yay.

[16] Çelikten, M. (2006). "Kültür ve Öğretmen Metaforları". Sosyal Bilimler Enstitüsü Dergisi. 2, 269-283.

[17] Çoban, M. (2016). "Değerler Eğitiminin Referansları Bağlamında Hacı Bektaş Velî’nin Makâlâtı”. Kahramanmaraş Sütçü İmam Üniversitesi Sosyal Bilimler Dergisi, 13/1: 1-22.

[18] Demir, M. (2009). "Batı Metaforu ve Doğu İstiaresinin Mukayeseli Olarak İncelenmesi”. Türkbilig. 18: 64-90.

[19] Genelge 2010/53. MEB Talim Terbiye Kurulu Başkanlığ Değerler Eğitimi Genelgesi.

[20] Gökçe, O. (2006). İçerik Analizi. Ankara: Siyasal Kitabevi.

[21] Güngör, E. (2000). Değerler Psikolojisi Üzerine Araştırmalar. İstanbul: Ötüken Neşriyat.

[22] Güven, A. Z. (2014). "Türk Efsanelerinin Değerler Eğitimi Bakımından İncelenmesi”. Mustafa Kemal Üniversitesi Sosyal Bilimler Enstitüsü Dergisi. 11 (26): 225-246.

[23] Güven, B. ve Güven, S. (2009). “İköğretim Öğrencilerinin Sosyal Bilgiler Dersinde Metafor Oluşturma Becerilerine İlişkin Nicel Bir İnceleme”. Kastamonu Eğitim Dergisi. 17 (2), 503-512.

[24] Hançerlioğlu, O. (1976). Felsefe Ansiklopedisi- Kavramlar ve Akımlar. C. 3. İstanbul: Remzi Kitabevi.

[25] Ceylan, D. (2018). "Büyük Tehlike: Duygusuz Nesil". http://www.egitimajansi.com/haber/buyuk-tehlike-duygusu z-nesil-haberi-51046h.html, [Erişim Tarihi: 02.08.2018].

[26] https://www.turkedebiyati.org/metafor/ [Erişim Tarihi: 31.07.2018]

[27] İnce, Ö. (2002). Yazınsal Söylem Üzerine. İstanbul: Türkiye İş Bankası Kültür Yay.

[28] Kale, E. ve Çiçek, Ü. (2015). "Hemşirelerin Kendi Mesleklerine İlişkin Metafor Algıları”. Sağlık ve Hemşirelik Yönetimi Dergisi. 2(3): 142-151.

[29] Kapkın, B., Çalışkan Z., Sağlam M. (2018). “Türkiye'de 1999-2017 Yılları Arasında Değerler Eğitimi Alanında Yapılmış Lisansüstü Çalışmaların İncelenmesi”. Değerler Eğitimi Dergisi. 16, (35): 185-209.

[30] Karasar, N. (2010). Bilimsel Araştırma Yöntemi. (21. Baskı). Ankara: Nobel.

[31] Keray Dinçel, B. ve Yılmaz, A. (2018). "Ortaokul Öğrencilerinin ve Türkçe Öğretmeni Adaylarının Türkçe Dersi ve Türkçe Öğretmeni Kavramlarına İlişkin Metaforları". Türkiye Sosyal Araştırmalar Dergisi. 22: 243-276.

[32] Kilcan, B. (2016). "Ignác Kúnos'un Kırk Dört Türk Peri Masalı Adlı Eserinin Değerler Açısından İncelenmesi”. Turkish Journal of Education. 5 (3): 82-94.

[33] Kılcan, B. ve Akbaba, B. (2013). “Sosyal Bilgiler Öğretim
Programında Yer Alan Kültürel Mirasa Duyarlılık Değerine İlişkin Öğrenci Algılarının İncelenmesi”. Journal of World of Turks. 5(3): 113-137.

[34] Kılcan, B. ve Akbaba, B. (2014). "Sosyal Bilgiler Öğretim Programında Yer Alan Estetik Değerine İlişkin Öğrenci Algılarının İncelenmesi”. Eğitimde Kuram ve Uygulama. 10 (4): 1047-1076.

[35] Kılcan, B., Akbaba, B. ve Gülbudak, B. (2017). "Altıncı ve Yedinci Sınıf Öğrencilerinin Hoca Ahmed Yesevî Algıları". Tarih Kültür ve Sanat Araştırmaları Dergisi. 6(2): 549-564.

[36] Kurtoğlu, F. S. (2017). “Âşık Veysel'in Şiirlerini Değerler Eğitimi Açısından Okumak". Türk Kültürü ve Hacı Bektaş Velî Araştırma Dergisi. 83: 101-123.

[37] Kurtoğlu, O. (2016). "Değer Eğitimi Açısından Ahilik ve Uygulamaları". Postmodern Çağda Ahilik (Edt: H. Örs). Ankara: Nobel Yay. 111-127.

[38] Kutlu, M. (2013). "Dostluk". https://www.yenisafak.com/y azarlar/mustafakutlu/dostluk-44355 [Erișim Tarihi 31.07.2018].

[39] Lakoff, G. ve Johnson, M. (2010). Metaforlar, Hayat, Anlam ve Dil (Çev. G. Y. Demir). İstanbul: Paradigma Yay.

[40] Levine, P. M. (2005). "Metaphors and Images of Classrooms". Kappa delta Pi Record. 41(4): 172-175.

[41] Mertol, H., Doğdu, M. ve Y1lar, B. (2013). "Üstün Zekâlı ve Yetenekli Öğrencilerin Sosyal Bilgiler Dersine İlişkin Metaforik Algıları". Üstün Yetenekli Eğitimi Araştırmaları Dergisi. 1(3): 176-183.

[42] Mete, F. ve Bağc1 Ayranc1, B. (2016). "Dil ve Edebiyata İlişkin Algıların Metaforlar Yoluyla İncelenmesi”. Dede Korkut Uluslararası Türk Dili ve Edebiyatı Araştırmaları Dergisi. 5 (11): 53-64.

[43] Moğul, S. (2012). Mehmet Akif Ersoy'un Safahat İsimli Eserinin Türkçe Eğitimi ve Değerler Eğitimi Açısından İncelenmesi. Yüksek Lisans Tezi. Kayseri: Erciyes Üniversitesi.

[44] Montaigne (2004). Denemeler (Çev. K. Çetinoğlu). İstanbul: Kum Saati Yay.

[45] Morgan, G. (1998). Yönetim ve Örgüt Teorilerinde Metafor (Çev. Gündüz Bulut). İstanbul: BZD Yay.

[46] Okan Akın, N. (2018). “Görsel Sanatlar Öğretmen Adaylarının Estetik Kavramına İlişsin Algılarının Metaforlarla İncelenmesi". Journal of Social and Humanities Sciences Research. 5 (18): 476-485.

[47] Onan, B. (2011). Anlama Sürecinde Türkçenin Yapısal İşlevleri. Ankara: Nobel Yay.

[48] Özensel, E. (2003). "Sosyolojik Bir Olgu Olarak Değer". Değerler Eğitimi Dergisi, 1(3): 217-239.

[49] Özsoy, Y. (2014). "Bilim ve Sanat Merkezi Öğrenci, Öğretmen ve Velilerinin Üstün Yetenekli Öğrenci Kavramına İlişskin Metaforları". Üstün Yetenekliler Eğitimi Araştırmaları Dergisi. 2(1), 74-87.

[50] Öztürk, Ç. (2007). "Sosyal Bilgiler, Sınıf ve Fen Bilgisi Öğretmen Adaylarının 'Coğrafya' Kavramına Yönelik Metafor Durumları”. Ahi Evran Üniversitesi Kırșehir Eğitim 
Fakültesi Dergisi. 8(2): 55-69.

[51] Patton, M. Q. (1987). How to Use Qualitative Methods in Evaluation. Newbury Park: SAGE.

[52] Pilav, S. ve Uslu Üstten, A. (2013). "Lise Öğrencilerinin Edebiyatla İlgili Algılarının Metaforlar Yoluyla Belirlenmesi Üzerine Bir Araştırma”. Turkish Studies. 8(8): 1073-1085.

[53] Saban, A. (2004). “Giriş Düzeyindeki Sınıf Öğretmeni Adaylarının Öğretmen Kavramına İlişkin İleri Sürdükleri Metaforlar”. Türk Eğitim Bilimleri Dergisi. 2(2): 131-155.

[54] Saban, A. (2008). "Okula İlişkin Metaforlar”. Kuram ve Uygulamada Eğitim Yönetimi. 55: 459-496.

[55] Saban, A. (2009). "Öğretmen Adaylarının Öğrenci Kavramına İlişkin Sahip Oldukları Zihinsel İmgeler”. Türk Eğitim Bilimleri Dergisi. 7(2): 281-326.

[56] Saraç, M. A.Y. (2007). Klâsik Edebiyat Bilgisi: Belâgat. İstanbul: $3 \mathrm{~F}$ Yay.

[57] Solmaz, S. (2016). "Değerler Eğitimi Açısından Klasik Türk Edebiyatı". 2016 Hoca Ahmet Yesevi Y1l Anısina Uluslararası Türk Dünyası Eğitim Bilimleri ve Sosyal Bilimler Kongresi Bildirileri (Edt. Y. Yeşil). Ankara: TES Yay. 579-593.

[58] Tanpınar, A. H. (1969). "Dostluğa ve Nurullah Ataç'a Dair”. Edebiyat Üzerine Makaleler. İstanbul: MEB Yay.

[59] Taşgın, A., İleritürk, D. ve Köse, E. (2018). “Ortaokul Öğrencilerinin Türkçe Dersi ve Türkçe Öğretmenine İlişkin Metaforları". Uluslararası Türkçe Edebiyat Kültür Eğitim Dergisi. 7(1): 397-410.

[60] TDEDÖP (2018). Ortaöğretim Türk Dili ve Edebiyatı Dersi $(9,10,11$ ve 12. Sinıflar) Öğretim Programı. Ankara: MEB Yay.

[61] TDK (2005). Türkçe Sözlük. Ankara: TDK Yay.

[62] TDK (2011). Türkçe sözlük. (On birinci basım). Ankara:
TDK Yay.

[63] TDK (2018a). Büyük Türkçe Sözlük. http://www.tdk.gov.tr /index.php?option $=$ com_bts\&arama=kelime\&guid=TDK.G TS.5acd055a7a8a22.07530951 [E.T. 31.07.2018].

[64] TDK (2018b). Büyük Türkçe Sözlük. http://www.tdk.gov.tr/index.php?option=com_gts\&arama= gts\&guid=TDK.GTS.5ad3166d3c6145.32891969 [E.T. 31.07.2018].

[65] Tortop, H. S. (2013). “Öğretmen Adaylarının Üniversite Hocası Hakkındaki Metaforları ve Bir Değerlendirme Aracı Olarak Metafor". Yükseköğretim ve Bilim Dergisi. 3 (2): 153-160.

[66] Tural, S. (1992). Kültürel Kimlik Üzerine Düşünceler. Ankara: Ecdâd Yay.

[67] Ulu Kalın, Ö. ve Koçoğlu, E. (2017). "Sosyal Bilgiler Öğretmen Adaylarının Bağımsızlık Değerine Karşı Metaforik Algıları". Ahi Evran Üniversitesi Kırşehir Eğitim Fakültesi Dergisi (KEFAD). 18 (2): 419-434.

[68] Uyar, Y. (2007). Türkçe Öğretiminde Kültür Aktarımı ve Kültürel Kimlik Geliştirme. Yüksek Lisans Tezi, Ankara: Gazi Üniversitesi.

[69] Veugelers, W. (2000). "Different Ways of Teaching Values". Educational Review. 25: 37-46.

[70] Yaman, E. (2014). Değerler Eğitimi. Ankara: Akçağ Yay.

[71] Yazıcı, K. (2006). "Değerler Eğitimine Genel Bir Bakış". Türklük Bilimi Araştırmaları. 19: 499-522.

[72] Yıldırım, A. ve Şimşek, H. (2006). "Sosyal Bilimlerde Nitel Araştırma Yöntemleri”. Ankara: Seçkin Yay.

[73] Yob, I. M. (2003). "Thinking Constructively With Metaphors". Studies in Philosophy and Education. 22: 127-138.

[74] Miles, M. B., \& Huberman, A. M. (1994). Qualitative Data Analysis. Thousand Oaks, CA: Sage Publications. 